Jurnal Teknologi Laboratorium

Vol.8, No.2, September 2019, pp. $70-75$

ISSN 2580-0191 (Online), ISSN 2338 - 5634 (Print)

DOI: 10.29238/teknolabjournal.v8i2.189

Journal homepage: https://www.teknolabjournal.com/index.php/Jtl/index

\title{
Total Lymfosit Count (TLC) with CD4 in HIVIAIDS Patients at Kupang
}

\author{
Adrianus Ola Wuan ${ }^{1 a^{*}}$, Ayorince Herlinalt Gloria Banunu ${ }^{2 b}$, Norma Tiku Kambuno ${ }^{1 \mathrm{c}}$ \\ ${ }^{1}$ Department of Medical Laboratory Technology, Poltekkes Kemenkes Kupang, Indonesia \\ ${ }^{2}$ Laboratory of Clinical Pathology, RSUD. W.Z. Johannes, Kupang, Indonesia \\ a Email address: lamabelawaa@ymail.com \\ b Email address: in05layauw@yahoo.com \\ ${ }^{c}$ Email address: norma.kambuno@gmail.com
}

\section{HIGHLIGHTS}

Total lymphocyte count is in line with the increase in CD4 counts

\section{ARTICLE INFO}

\section{Article history}

Received Date: July $12^{\text {nd }}, 2019$

Revised Date: September18 ${ }^{\text {th }}, 2019$

Accepted Date: September $27^{\text {th }}, 2019$

\section{Keywords:}

CD4

Total lymphocyte

HIV

AIDS

\begin{abstract}
Human Immunodeficiency Virus (HIV) is a retrovirus originating from the retroviridae family of the genus lentivirus that infects and damages cells that have a molecule Cluster of Differentiation 4 (CD4), especially $\mathrm{T}$ lymphocytes that have receptors with high affinity for HIV. Total lymphocyte count / TLC has been proposed as an alternative guide to CD4 in limited health facilities. This study aims to determine the correlation between Total Lymphocyte Count (TLC) and CD4 in HIVIAIDS patients in the W.Z. Johannes Kupang hospital. The type of this research was observational analytic with a cross-sectional design. The study was conducted on 121 samples of patients who performed CD4 examination and Total Lymphocytic Count (TLC) in the laboratory of W.Z.Johannes Kupang Hospital. The Spearman correlation test shows a significance value of 0,000 with a Spearman correlation value of 0.799 . Based on the results of this study it can be concluded that there is a significant correlation between Total Lymphocyte Count and CD4 and shows the direction of positive correlation with a very strong relationship, where the increase in the number of Total Lymphocyte Count is in line with the increase in CD4 counts.
\end{abstract}

\section{*Corresponding Author:}

Adrianus Ola Wuan

Department of Medical Laboratory Technology, Poltekkes Kemenkes Kupang

JI. Farmasi Kelurahan Liliba Kec Oebobo, Kupang, Nusa Tenggara Timur, Indonesia

Email: lamabelawaa@ymail.com

\section{INTRODUCTION}

Based on Health ministry reported cases of Human Immunodeficiency Virus (HIV) from 2005 to December 2017 amounted to 280,623 people. The cumulative number of AIDS from 1987 to December 2017 was 102,667 people. ${ }^{1,2}$ The highest number of cases of infection were DKI Jakarta with 51,981 people, followed by East Java with 39,633 people, Papua 29,083 people, West Java 28,964 people and Central Java with 22,292 people. ${ }^{2}, \underline{3}$

Based on data from the Directorate General of Disease Prevention and Control, the Ministry of Health of the Republic of Indonesia in 2017 in East Nusa Tenggara Province the 
number of HIV infections reported up to December 2017 was 3,464 people and AIDS cases were 1,965 people. 2.4

HIV is a retrovirus originating from the retroviridae family of the genus lentivirus which infects and damages cells that have Cluster of Differentiation 4 (CD4) molecules, especially T lymphocytes that have receptors with high affinity for HIV. ${ }^{-}$This viral infection results in a continuous decline in the immune system. $\frac{6,7}{5}$ The main target of HIV infection is through CD4 cells. Normal CD4 cell count ranges from $500-1600$ cells $/ \mathrm{mm}^{3}$ of blood. CD4 cell count is a way to assess the immunity status of people with HIV-AIDS (ODHA). CD4 examination completes a clinical examination to determine patients who need prophylactic $I O$ and antiretroviral therapy. ${ }^{1}$

Several studies have shown that to monitor the condition of HIV patients can use several parameters including delayed-type hypersensitivity responses, haemoglobin $(\mathrm{Hb})^{\underline{8}}$, total lymphocyte count (TLC), serum albumin levels, and body mass index., $\frac{90,11}{\text { The gold }}$ standard for CD4 examination is to use a flow meter, but it requires expensive equipment, so it is difficult to obtain in areas with limited facilities. $\frac{10,12,13}{13}$ WHO's anti-retroviral therapy guidelines state that if CD4 count cannot be obtained, the total lymphocyte count (TLC) will be used as a replacement. ${ }^{14}$

General Hospital Prof. DR. W. Z. Johannes Kupang has a special clinic for Counseling and Testing (Voluntary Counseling and Testing / VCT) as well as Care, Support and Treatment (Care, Support and Treatment / CST), namely the VCT CCT Sobat Clinic. A number of Patient visit at the VCT Sobat clinic at General Hospital W.Z.Johannes in 2018 were 9,244 people, with 229 HIV positive cases. The total cumulative ODHA who get ARV therapy in CST Sobat clinic until September 2018 was 627 people. Monitoring of CD4 count can be done at Laboratory of General Hospital Prof. DR. W. Z. Johannes Kupang, but the availability of reagents is very limited. Examination data shows that in 2017 Laboratory of General Hospital Prof. DR. W. Z. Johannes Kupang can only perform 70 CD4 examinations, whereas in 2018 only 50 reagents are received. This amount is very lacking, considering that the CD4 examination is not only used to determine the start of treatment in new patients but also is used to assess the success of ARV treatment. Decreased CD4 cell count results in reduced TLC as evidenced by Resindra et al., that TLC can be used as a replacement check for CD4 cell count in monitoring HIV infection. $\frac{15}{-}$ The results of research conducted by Sanjaya's et al., also support the existence of a moderate correlation of TLC with CD4 cell count in all aspects of study. $\underline{16}$

There are differences in the results of the research found both conducted abroad and in Indonesia as well as the limited research on the relationship between TLC and CD4 in Indonesia, especially in East Nusa Tenggara. Akinola et al., states that there is no strong correlation between TLC and CD4 (female: $r=0.473$; male $r=0.384$ ). $\frac{17}{\text { Irianto }}$ et al., also states There is a weak correlation between the number of lymphocytes with the number of CD4 cells, so the calculation of the number of lymphocytes cannot be used as an alternative in monitoring therapy. $\frac{18}{-}$ The purpose of this study was to find the correlation between Total Lymphocyte Count (TLC) with CD4 in HIVIAIDS patients at General Hospital Prof. DR. W. Z. Johannes Kupang.

\section{MATERIALS AND METHOD}

This research was conducted at the Clinical Pathology Installation General Hospital W. Z. Johannes Kupang in April 2019. The sample study was data on HIVIAIDS patients who performed routine blood/total lymphocyte count and CD4 counts and obtained 121 patients. Data was collected and analyzed using SPSS for Windows software.

This study was an analytic observational study with a cross-sectional design. The sample of this study were patients diagnosed with HIV from the VCT / CST Clinic of General Hospital Prof. DR. W. Z. Johannes Kupang, who conducted routine CD4 and blood/lymphocyte examinations in the laboratory of the General Hospital Prof. DR. W. Z. Johannes Kupang. This research has received ethical approval through the ethics committee of the Faculty of Medicine, Gadjah Mada University with number: KE / 223 / EC / 2016.

The criteria of the sample were patients diagnosed with HIV from the VCT / CST Clinic of General hospital Prof. Dr. W.Z. Johannes Kupang, which conducts routine CD4 and blood/lymphocyte examinations in the laboratory. We used secondary data in the form of 
patient medical records recorded General Hospital Prof. DR. W. Z. Johannes Kupang. The variables studied in this study were CD4 count that was calculated using the PIMA Analyzer with cell / $\mu$ l unit and Total Lymphocyte Count (TLC) calculated by the Automated Hematology Analyzer Sismex XN 550 with cell / $\mu$ l unit. Pearson correlation test was used to find the correlation between Total Lymphocyte Count and CD4 count if the data were normally distributed. If the data are not normally distributed, then the Spearman correlation test would be used.

\section{RESULTS AND DISCUSSION}

This research was conducted at the Clinical Pathology Installation General hospital Prof. DR. W. Z. Johannes Kupang in April 2019. The sample study was data on HIVIAIDS patients who performed routine blood/total lymphocyte count and CD4 counts and obtained 121 patients. Data was collected and analyzed using statistical software.

Table 1. Distribution of Samples based on CD4 Count and Total Lymphocyte Count

\begin{tabular}{cccccc}
\hline \multirow{2}{*}{ Characteristics } & \multicolumn{2}{c}{ Man } & \multicolumn{2}{c}{ Female } \\
\cline { 3 - 6 } & & Total & $\begin{array}{c}\text { Percentage } \\
(\%)\end{array}$ & Total & $\begin{array}{c}\text { Percentage } \\
(\%)\end{array}$ \\
\hline CD4 Count & & & & \\
& $>500$ & 5 & 6.4 & 7 & 16.3 \\
& $350-499$ & 5 & 6.4 & 6 & 13.9 \\
& $200-349$ & 11 & 14.1 & 11 & 25.6 \\
& $<200$ & 57 & 73.1 & 19 & 44.2 \\
& Total & 78 & 100 & 43 & 100 \\
\hline Lymphocyte Count & & & & \\
& $<1000$ & 33 & 42.3 & 16 & 37.2 \\
& $>1000$ & 45 & 57.7 & 27 & 62.8 \\
& Total & 78 & 100 & 43 & 100 \\
\hline
\end{tabular}

Based on table 1, the percentage of total lymphocyte count in this study is more than 1000 cells / $\mu \mathrm{l}$, while the percentage of CD4 is less than 200 cells / $\mu \mathrm{l}$. After grouping based on CD4 count, in the CD4 group that is more than 350 cells / $\mu$ l, and the total lymphocyte count still exceeds 1000 cells / $\mu$ l. Meanwhile, in the CD4 group that is less than 200 cells / $\mu$ l, there is $95.9 \%$ of the study sample with a total lymphocyte count that is less than 1000 cells $/ \mu$ l. This is probably due to the fact that no definitive information was obtained from the study samples regarding the patient's infection phase, whether people with HIV were in the acute infection phase or were still in the latent infection phase where most lymphocyte counts were still within normal limits, but there had been a decline in CD4 counts. ${ }^{12}$ These results also provide a general picture that the decrease in total lymphocyte count mostly occurs only in patients with CD4 count that is less than 200 cells / $\mu$ l.

Table 2. Spearman Correlation Test Results

\begin{tabular}{lccc}
\hline Variable & $N$ & Correlation Coefficient & Sig. \\
\hline Total Lymphocyte Count & 121 & $0.799^{* * *}$ & 0.000 \\
CD4 & 121 & & \\
\hline
\end{tabular}

The results of statistical analysis with the Spearman correlation test on the entire study samples showed that there was a significant correlation between Total Lymphocyte Count and CD4 $(p=0.000)$. They showed the direction of a positive correlation with a very strong relationship $(r=0.799)$.

The existence of a positive correlation between Total Lymphocyte Count (TLC) with CD4 in HIVIAIDS patients is based on the theory that a decrease in Total Lymphocyte Count (TLC) can cause a decrease in CD4 count. CD4 is a part of lymphocytes. Lymphocytes consist of two subtypes, namely T lymphocytes and B lymphocytes. B lymphocytes will be converted into plasmocytes to form antibodies in the humoral defence system. $T$ lymphocytes which are primary cells of the cellular defence system that can be divided into helper T cells (CD4) and 
suppressor $\mathrm{T}$ cells (CD8). CD4 cells are the largest part of $\mathrm{T}$ lymphocytes, which is 34$67 \% \cdot \underline{3}, \underline{19}, \underline{20}$

In HIV infection, selective reduction in CD4 cells is found due to the direct effects of the virus or the body's immune response. This selective reduction is due to the tropism of the virus to infect CD4 cells. As part of lymphocytes, reduction of CD4 cells count will also decrease Total Lymphocyte Count. ${ }^{19}$ Coinfection with other diseases such as Hepatitis B, Hepatitis C, and tuberculosis will further reduce the patient's immune system so that it will cause a CD4 cell count to decrease.$^{\underline{20}, \underline{21}}$ This situation is also called an opportunistic infection. $.^{2}, \underline{21}$

The results of this study did not differ significantly from research conducted by Sanjaya, et al., on 350 subjects at Hospital of Dr. Hasan Sadikin Bandung which divided by WHO clinical-stage, and then the data were analyzed using Pearson correlation analysis and Fisher's r-to-z transformation. Results of the study obtained a good and statistically significant correlation between the number of CD4 lymphocytes and the number of lymphocytes at all stages of HIV infection.

The results of research conducted by the Sanjaya et al ${ }^{17}$, have a slight difference which states that in every clinical-stage, they have moderate correlation, whereas in this study the statistical test results show a strong correlation. This is because, in this study, researchers only tested in general, and only divided the characteristics of the research based on sex.

A positive correlation between lymphocyte count and CD4 lymphocyte count is also

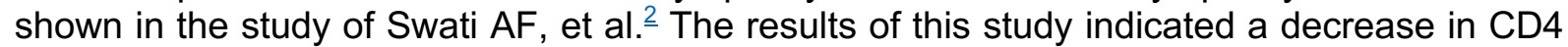
lymphocytes count followed by a decrease in the lymphocytes count. The study of Swati AF, et al. has a difference with this study in which retrospective data collection is performed on the medical records of children who have HIV who are hospitalized and subjects are controlled by several variables such as sex, age, (Body Mass Index) BMI, haemoglobin level, leukocytes count, and platelets. ${ }^{\text {? }}$

The results of this study differ from those of Akinola et al., In which the study states that there is no strong correlation between TLC and CD4 (women: $r=0.473$; men: $r=0.384$ ). ${ }^{17}$ The difference from this study lies in the study sample, where Akinola et al. take study samples from patients with HIV-1 antibodies but have not yet started the ARV therapy. Others study states the same thing that there is a strong correlation between CD4 and TLC, but that correlation weakens when patients were divided into groups according to their CD4 count.., 13

The results of strong correlations in this study were also possible because this study only analyzed the correlation of total lymphocyte count and CD4 count in general, without dividing in detail from age group, clinical-stage, duration of ARV therapy or other factors affecting total lymphocyte count and CD4 count. The limitations of this study are expected to be a consideration for understanding the results of this study.

\section{CONCLUSION}

There was a significant correlation between Total Lymphocyte Count and CD4. The results of this study also showed the direction of positive correlation with a very strong relationship, where the increase in the Total Lymphocyte Count was in line with the increase in CD4 count.

\section{ACKNOWLEDGEMENT}

We gratefully acknowledge the head of general hospital Prof. DR. W. Z. Johannes Kubang. Dr. R.H. Kristina SKM, Make's, head of Health Polytechnic of Ministry of Health in Kubang.

\section{CONFLICT OF INTEREST}

We declared in this work, not any conflict of interest.

\section{REFERENCE}

1. Jamil KF. Profil Kadar CD4 Terhadap Infeksi Oportunistik pada Penderita Human Immunodeficiency Virus/Acquired Immunodeficiency Syndrome (HIVIAIDS) di RSUD dr. Zainoel Abidin Banda Aceh. J Kedokt Syiah Kuala. 2014;14(2):76-80.

2. Kementerian Kesehatan RI. Laporan Situasi Perkembangan HIVIAIDS Dan PIMS Di Indonesia Tahun 2018. Jakarta; 2018. doi:10.1017/CBO9781107415324.004. 
3. Rostina R, Aprianti S, Arif M. Prediksi Jumlah Sel Limfosit T Cd4+ Menggunakan Nilai Tlc (Total Lymphocyte Count) Pada Penderita Hiv/Aids. Indones J Clin Pathol Med Lab. 2018;14(2):64.

4. Kambuno, N., Sari, A., Nurdin, K., Novicadlitha, Y., \& Siregar I. The relation of blood donors' characteristic toward prevalences of HBsAg and Anti-HCV on blood transfussion unit of PMI in Province of East Nusa Tenggara. In: Waangsir F, Kase S, eds. Proceeding 1st. International Conference Health Polytechnic of Kupang. Kupang, East Nusa Tenggara: Health Polytechnic of Kupang; 2018:303-310.

5. Kwantwi LB, Tunu BK, Boateng D, Quansah DY. Body Mass Index, Haemoglobin, and Total Lymphocyte Count as a Surrogate for CD4 Count in Resource Limited Settings. J Biomarkers. 2017;2017:1-6. doi:10.1155/2017/7907352.

6. Anto EO, Obirikorang $\mathrm{C}$, Acheampong $\mathrm{E}$, et al. Evaluation of individual and combined markers of urine dipstick parameters and total lymphocyte count as a substitute for CD4 count in low-resource communities in Ghana. Dis Markers. 2018;2018. doi:10.1155/2018/7485942.

7. Widiyanti M, Hutapea H. Hubungan Jumlah Cluster of Differentiation 4 (CD4) dengan Infeksi Oportunistik Pada Pasien HIVIAIDS di Rumah Sakit Umum Daerah (RSUD) DOK II Jayapura. J Biol Papua. 2016;7(1):16-21.

8. $\quad$ Fransiska YY, Kurniawaty E. Anemia pada Infeksi HIV. J Major. 2015;4(9):123-128.

9. Karanth S, Rau N, Shanbhogue V, Pruthvi B, Gupta A, Kamath A. Utility of total lymphocyte count as a surrogate for absolute CD4 count in the adult Indian HIV population: A prospective study. Avicenna J Med. 2014;4(1):1. doi:10.4103/22310770.127413.

10. Rafatpanah H, Essmailian L, Hedayati-Moghaddam MR, et al. Evaluation of non-viral surrogate markers as predictive indicators for monitoring progression of human immunodeficiency virus infection: An eight-year analysis in a regional center. Jpn J Infect Dis. 2016;69(1):39-44.

11. Gholamzadeh Baeis M, Amiri G, Miladinia M. The effects of setarud on the immunological status of HIV-positive patients: Efficacy of a novel multi-herbal drug. Avicenna J phytomedicine. 2017;7(3):232-241.

12. Astari L, Sawitri SY HD. Viral Load pada infeksi HIV. Berk IImu Kesehat Kulit Kelamin. 2009;21(1):31-39.

13. Chen J, Li W, Huang X, et al. Evaluating Total Lymphocyte Count as a Surrogate Marker for CD4 Cell Count in the Management of HIV-Infected Patients in Resource-Limited \begin{tabular}{llllll}
\hline Settings: A Study from & China. PLoS One. 2013;8(7):4-9.
\end{tabular} doi:10.1371/journal.pone.0069704

14. Greene E, Pack A, Stanton J, et al. "It makes you Feel like someone cares" acceptability of a financial incentive intervention for HIV viral suppression in the HPTN 065 (TLCPlus) study. PLoS One. 2017;12(2):1-18. doi:10.1371/journal.pone.0170686.

15. I Made Wikrama Resindra, Ilsa Hunaifi, I Gede Yasa Asmara. Korelasi antara Jumlah Limfosit Total dan Limfosit Cd4+ pada Pasien HIVIAIDS di RSUD Provinsi NTB. Unram Med J. 2019;8(2):24. doi:10.29303/jku.v8i2.339.

16. Sanjaya A, Sugiarto C, Jonathan R. Correlation of Total Lymphocyte Count with CD4 Count in HIVIAIDS Patients. J Med Heal. 2015;1(1):0-7. doi:10.28932/jmh.v1i1.500.

17. Akinola NO, Olasode O, Adediran IA, et al. The Search for a Predictor of CD4 Cell Count Continues: Total Lymphocyte Count Is Not a Substitute for CD4 Cell Count in the Management of HIV-Infected Individuals in a Resource-Limited Setting. Clin Infect Dis. 2004;39(4):579-581.

18. Irianto HP. Jumlah limfosit sebelum dan sesudah terapi antiretroviral dan korelasinya dengan jumlah sel cd4. 2016.

19. Aman AK, . T, . R. Pemeriksaan CD4 Hubungannya dengan Stadium Penyakit HIV. Indones J Clin Pathol Med Lab. 2018;14(3):93. doi:10.24293/ijcpml.v14i3.926.

20. Nyoko YO, Putra IWGAE, Sawitri AAS. Hubungan Karakteristik Demografi, Klinis dan Faktor Risiko Terinfeksi HIV dengan Koinfeksi HIV/TB di Klinik Amertha Yayasan Kerti Praja Denpasar. Public Heal Prev Med Arch. 2014;2(2):95.

21. Widiyanti M, Fitriana E, Iriani E. Karakteristik Pasien Koinfeksi Tb-Hiv Di Rumah Sakit Mitra Masyarakat Mimika Papua. Sel J Penelit Kesehat. 2017;3(2):49-55. 
doi:10.22435/sel.v3i2.6382.49-55.

22. Swity AF, Setiabudi D, Garna H. Korelasi Total Lymphocyte Count terhadap CD4 pada anak dengan Infeksi Human Immunodeficiency Virus. Sari Pediatr. 2016;15(2):81. 